\title{
Improving Business Student Writing - A Ten-Step Model
}

\author{
Cam Caldwell ${ }^{1} \&$ Noof Jasim Hamdan Al-Ajmi ${ }^{1}$ \\ ${ }^{1}$ Modern College of Business and Science, Muscat, Oman \\ Correspondence: Cam Caldwell, Modern College of Business and Science, Muscat, Oman
}

Received: December 29, 2017

Accepted: January 18, 2018

Online Published: February 6, 2018

doi:10.5430/bmr.v7n1p35

URL: https://doi.org/10.5430/bmr.v7n1p35

\begin{abstract}
The ability to write effectively has been widely acknowledged as a consistent problem of business graduates - even at the best colleges and universities where English is the native language of the students. This paper identifies the challenges facing business students in becoming effective writers and identifies a model for improving business student writing which business schools at colleges and universities can apply.

Objective: The purposes of this paper are to address the problem of ineffective business student writing and to suggest a ten-step model for colleges and universities to implement as they seek to improve the quality of their business graduates' writing skills. We begin by briefly summarizing the writing limitations of many business school graduates, citing examples from the scholarly literature and feedback from employers. After identifying key issues in effective writing identified by scholars, we then present ten specific components of a model for improving business writing skills and explain how each of those components fits within a comprehensive program to improve business writing. We conclude this paper with a challenge to business faculty, department chairs, and deans to raise the bar by incorporating this ten-step model for the benefit of their own students and for those students' future employers.
\end{abstract}

Method: This is a conceptual paper that examines and integrates the academic literature with concepts related to improving business student graduate skills, particularly related to their ineffective writing abilities.

Results: The paper identifies ten specific steps that can be applied as part of a holistic program to remediate ineffective student writing for business school students.

Conclusion: Business schools have long been ineffective in preparing their graduates to write effectively. This ten-step model presents a resource to enable business faculty and administrators to honor their obligation to their students, future employers, and society.

Keywords: Improving Writing, Business School Obligations, Written Communication, Shortcomings of Business Graduates

\section{Introduction}

The inability of college graduates to communicate in writing is a serious problem facing employers of all types and half of all graduating seniors have acknowledged that their college experience has failed to improve their ability to write effectively (Moore, 2016). United Kingdom employers complained that new university graduates "can't string a simple sentence together" (Kotzee \& Johnson, 2011) and Sultan (2013, p. 139) called poor academic writing "a major cause of concern for universities." Silicon Valley employers in the USA offer similar criticisms about college and university graduates' inability to write effectively (Stevens, 2005) and many employers cite the inability to write as the biggest shortcoming of business graduates, Even the best colleges and universities decry the inability of business school graduates to write effectively -- a concern for decades (Macdonald, 1995; Bartlett, 2003).

The purposes of this paper are to address the problem of ineffective business student writing and to suggest a ten-step model for colleges and universities to implement as they seek to improve the quality of their business graduates' writing skills. We begin by briefly summarizing the writing limitations of many business school graduates, citing examples from the scholarly literature and feedback from employers. After identifying key issues in effective writing identified by scholars, we then present ten specific components of a model for improving business writing skills and explain how each of those components fits within a comprehensive program to improve business writing. We conclude this paper with a challenge to business faculty, department chairs, and deans to raise the bar by incorporating this ten-step model for the benefit of their own students and for those students' future employers. 


\section{Improving Writing is Difficult}

Even with the best efforts of many outstanding business schools, improving student writing has been far from easy (Bartlett, 2003). Bartlett (2003) reported that top American universities from Duke and Princeton to Harvard have struggled unsuccessfully with the task of assisting business students to upgrade the quality of their writing skills despite the fact that their students consistently rank among the "best and brightest" of academic candidates. Developing the ability to write simply and clearly is sometimes considered to be a lost art that eludes scholars of all types - including PhDs who struggle to get their work published (cf. Whetten, 2001). David Whetten (2001), former President of the international. Academy of Management and editor of its most prestigious academic journal, related the story of his own struggles as a new $\mathrm{PhD}$ graduate from Cornell University at the beginning of his academic career - and Whetten's experience mirrors that of many doctoral program graduates who face the challenges of "publish or perish" today (Hasan, 2016).

Teaching students to write effectively is no easy challenge (Kahn, Johannessen, McCann \& Smagorinsky, 2012). The elementary and high school classrooms in many cities worldwide are fraught with students who come from difficult family backgrounds, with questionable role models, and sub-standard economic and living conditions - and those who graduate from high schools frequently lack basic skills required to succeed at the university level (Fee, Greenan, $\&$ Wall, 2010). Writing effectively is made more difficult due to the extremely high $47 \%$ dropout rate for high school age students in the 50 largest US cities (Dillon, 2009) - compounded by the fact that $27 \%$ of those who do graduate fail to read at the required level and $70 \%$ of high school graduates require some form of remediation to be college ready (Rutenberg, 2009).

Although it is a knowledge-, wisdom-, and information-based economy (Covey, 2004), nearly two-thirds of high school seniors in the USA lack adequate college preparation and require academic remediation to be ready for tertiary studies (Camera, 2016). The challenges facing the 1.5 billion people worldwide who are non-native English speakers to write effectively in English are even more difficult due to the paucity of qualified instructors and the inherent complexity of the English language (Bentley, 2014). The problem of business students developing writing skills is daunting and the need to address those skills has been made more difficult due to the reality that so many college and university professors are non-native English speakers themselves. Consequently, the Academy for Advancement of Collegiate Schools of Business, the "gold standard" of business school accreditation, has eliminated the requirement for MBA graduates to write effectively, despite the fact that employers consider the ability to write to be profoundly important (Caldwell, White \& Red Owl, 2007).

\section{Elements of Effective Writing}

Although writing effectively is a difficult challenge, business writing is a critical element to business success in virtually every area of business from sales and marketing to personnel and business law (Davidson \& Emig, 2015). According to Davidson and Emig (2015, p. 5), "business people spend 30-40 percent of their work time writing." Fortunately, Bryan Garner (2013), author of a Harvard Business Review guide to better business writing, observed that effective writing is a skill that can be cultivated and improved.

Herbert Simon (1997), the Nobel Prize winning author of Administrative Behavior -- cited as the fifth most influential management book of all time (Bedeian \& Wren, 2001) - observed that a man who had a brilliant understanding of key concepts but who did not effectively communicate those concepts to others in his organization was unable to benefit that organization. Business writing, to be truly useful, must be meaningfully communicated to a specific audience for a clear purpose and that purpose must be one that is important to its readers (Max, 2016).

The reality is that the skills of business writing are elusive and successful writing often takes painstaking effort (Canavor, 2018) -- even for the best of writers (Selingo, 2017). For example, Martin Chilton (2012) noted that the brilliant Ernest Hemingway wrote and rewrote forty-seven different endings to his novel, Farewell to Arms, in his struggle "to get the words right." The myth that "Writing is easy" is simply not correct and, like any worthwhile skill, the ability to write effectively takes time and effort to develop (Garner, 2013).

Davidson and Emig (2015) provide a summary of ten qualities of powerful writing. Effective writing consists of the following elements.

1) Meets a Need - Business writing must accomplish an important purpose.

2) Appropriate Tone - Writing must be respectful of its audience.

3) Informative Content - A substantive message is clearly expressed.

4) Movement - The message goes somewhere and makes sense. 
5) Readable Format - The message format is easy to read and understand.

6) Conciseness - Words are simple, concrete, and precise.

7) Voice - Words communicate naturally, as in normal conversation.

8) Originality - The message communicates something new or an old message in a new way.

9) Rhythm - The writing flows naturally and smoothly.

10) Mechanics - Grammar, spelling, punctuation, and usage are appropriate and correct.

Although these qualities are relatively simple to enumerate, they can be difficult to achieve. Despite the fact that college and university students may have written many papers throughout their pre-college years, they may still be far from effective at communicating in writing at the tertiary level or within a business context.

\section{The Ten-Step Model}

The purpose of this section is to present ten specific steps which, when applied as part of a comprehensive approach to improving business student writing skills, is likely to exponentially improve those capabilities and prepare graduates to write more effectively as employees. Each of these ten steps is based upon well-established organizational and educational principles and the ten-step model is the integration of those principles into a comprehensive writing improvement program.

1) Obtain Organization Commitment. The importance of developing business student writing skills must be understood, appreciated, and supported with resources at all levels of a college or university. Top administrators must fully endorse the goals and objectives and express that commitment to heads of departments, faculty, support staff, and students. Top-down commitment is critical to the success of any major change initiative and is most effective when leaders offer visible and regular support of any change (Scholtes \& Joiner, 2003). But faculty in Business and related departments must also be fully committed to "Writing Across the Curriculum" and to giving students the opportunity to develop their writing skills (Saulnier, 2016). Finally, students must understand and buy-in to becoming full "owners and partners" in their own commitment to improving their writing skills (cf. Block, 2013).

2) Create a Faculty Support Team. Business faculty must become fully-engaged and committed advocates of improving writing skills by requiring students to complete writing assignments and to meet high professional standards in virtually every Business course (Saulnier, 2016). The entire Business School faculty must become a united faculty support team and demonstrate that commitment by willingly providing students with detailed feedback about writing assignments. In addition, faculty from other disciplines should also be encouraged to hold students accountable to high writing standards, particularly in courses requiring analysis and problem-solving skills. Faculty must not only hold students accountable for their writing abilities but must constantly improve their skills as well (Bartlett, 2003).

3) Engage Student Ownership. Student peers have the greatest impact upon student behaviors and the success of a writing improvement program can be greatly enhanced by student ownership and commitment including the process of peer monitoring of student plagiarism and violations of academic integrity (Caldwell, 2010). Student leaders who understand the importance of developing writing skills as a condition precedent for professional success can play a significant role in educating their peers and outstanding student writers who have developed excellent skills can be both role models and tutors for other students.

4) Pre-assess Student Writing Skills. For each business student they should be pre-assessed upon entrance into the college or university to document their writing level, weaknesses, and areas needing improvement. That benchmarking should provide each student with a customized remediation plan, if remediation is necessary. Improvement must be focused on the areas where each individual student is weak. For each business course that a student takes, (s)he should also be pre-assessed and provided with coaching and support at his or her individual level of writing competence. Vocabulary, spelling, reading comprehension, grammatical knowledge, organization of ideas, and other key elements of effective writing should be included in each pre-assessment (Varner \& Pomerenke, 1998).

5) Incorporate Clear Rubrics. Rubrics and examples of expected writing assignments are powerful teaching tools and can clarify in students' minds the key elements to include in a written assignment and the relative value of each of those elements (Appleman, 2017). Rubrics have been well established as an important teaching tool and can help students to understand where to focus their efforts, what to include, and why each element of the rubric is important (Routman, 2004; Mannino \& Shoaf, 2007). 
6) Utilize Software Resources. Commercially available software resources can be tremendously helpful to assist business students to improve their writing skills and to self-check their initial writing drafts. Turnitin.com (2017) contains an outstanding set of aids to provide students with specific feedback about writing quality. Grammarly (Grammarly, Inc. 2017) is also an excellent resource for checking grammar and usage. Business faculty need to specifically teach their students how to use these software tools as part of a class in Business Research and Writing which is taught to all business students at the beginning of their academic careers. Faculty in advanced courses should also remind students who obviously have not used this software when those students turn in a sub-standard writing assignment.

7) Establish a Business Writing Center. Creating a Business Writing Center to assist business students with writing assignments can be a powerful tool to help students to identify errors, learn how to self-check their own work, and develop writing skills that enable them to communicate simply, clearly, and powerfully (Griffin, 2001). Business Writing Centers can be staffed by a full-time faculty member, multiple faculty members on a part-time basis, and volunteer and compensated student tutors. Clear ground rules which define the expectations and requirements provided to students are a necessity for maintaining standards of both quality and control, but the focus of the Business Writing Center should always be to teach students to identify their writing errors, to improve their writing quality, and to develop the skills to be an effective writer upon graduation (May, Thompson, \& Hebblethwaite, 2012).

8) Involve Student Peer Support. Building into the classroom opportunities for student peer support from students who are outstanding writers can have a powerful effect in helping those excellent student peers to assist their colleagues. Care should be given to give those student peer leaders full academic recognition for their contribution as peer leaders. Student peers should also be encouraged to play an active role in programs designed to help other students to improve their writing - including serving as student coaches in the Business Writing Center. This opportunity for peers to help their colleagues develops leadership skills, increases confidence, and enables outstanding writers to serve others. Compensating student peers as Business Writing Center tutors can be accomplished in many ways, including tuition deferment or a scholarship, in addition to enabling qualified students to earn money and be recognized for their contribution on their resumes. Some schools create "Business Writing Fellows" as a distinction for outstanding peer role models (Parent, Nielsen-Dube, Stowe, Schwartz, Sendall \& Cain, 2011).

9) Research and Integrate Others' Successes. Tracking the successes of other colleges and universities in improving student writing skills enables a school to identify whether the programs and innovations introduced elsewhere could be contextually consistent with the culture and context of one's own academic institution (Sundem, 2006). "One size" or program successfully implemented elsewhere definitely does not fit all circumstances. A careful determination should be made as to whether the unique context of another academic institution may equate with that of one's own school setting. Sharing information with other schools that are currently involved in improving student writing can only benefit both parties, assuming that a careful analysis of the context of a program's success is taken into consideration.

10) Post-test and Document. Post-testing student progress in writing identifies both student progress and the relative success of individualized methods to improve student writing (Ruppert, Weihrich \& Carpenter, 2012). The post-test process should be used in many ways. Before students are allowed admission into upper level business classes, they should be required to meet an established standard of writing and research proficiency in order to succeed in those advanced classes. All business students should be expected to complete writing assignments across the business curriculum and students whose performance falls below the expected standard should also be identified and required to receive additional research and writing assistance through the Business Writing Center. Finally, all graduating business students should be required to successfully pass a writing competency assessment as a condition of graduation.

Although there are never guarantees that an academic program will always be successful, these ten elements or steps will enable business schools to improve the likelihood that their business students will be able to meet the writing standards required by employers.

\section{A Challenge to Business Schools}

Academic institutions, and Schools of Business, have frequently been criticized for their failure to remain current with the needs of the business community (Pfeffer \& Fong, 2002; Mintzberg, 2005). "It's academic" has unfortunately come to mean that an idea is perceived to be ivory tower, impractical, far too theoretical, and lacking 
in practical value (Caldwell \& Jeane, 2007). Business schools have been criticized for failing to prepare graduates to work in the real world and for their inability to meet the needs of business employers (Mintzberg, 2005).

The ability to write effectively is widely acknowledged as a critical skill of business graduates - yet a skill that many business graduates consistently fail to demonstrate (Kotzee \& Johnson, 2011). Preparing business graduates to perform effectively on the job is a moral duty that business schools owe their students (Caldwell, Karri \& Matula, 2005). Employers struggle worldwide to compete in a global marketplace (Collins \& Porras, 2004), and the modern society has been unable to deal successfully with a numbing list of compelling problems (Friedman, 2009; Anderson, Ndalamba \& Caldwell, 2017). Solving the problems facing business and society will demand that business graduates demonstrate the ability to communicate effectively in writing. Business schools and their leaders can benefit by incorporating this ten-step model and their challenge is to raise the bar of their performance in preparing their graduates to become effective communicators if the problems facing businesses and communities are to be effectively addressed.

\section{References}

Anderson, V., Ndalamba, K. K., \& Caldwell, C. (2017). Social Responsibility in a Troubled World: A Virtuous Perspective. International Journal of Public Leadership, 13(2), 98-115. https://doi.org/10.1108/IJPL-10-2016-0034

Appleman, J. E. (2017). 10 Steps to Successful Business Writing ( $2^{\text {nd }}$ ed.). Alexandria, VA: Association for Talent Development.

Bartlett, T. (2003). Why Johnny Can't Write, Even Though He Went to Princeton: Many Top Colleges Fear that Their Students Lack Basic Composition Skills. Chronicle of Higher Education, Jan 3, 2003, 49(17), A39.

Bedeian, A. G. \& Wren, D. A. (2001). Most Influential Management Books of the $20^{\text {th }}$ Century. Organization Dynamics, 29(3), 221-225. https://doi.org/10.1016/S0090-2616(01)00022-5

Bentley, J. (2014). Report from TESOL 2014: 1.5 Billion English Learners Worldwide. Chicago, IL: International TEFL Academy found online on December 19, 2017 at https://www.internationalteflacademy.com/blog/bid/205659/Report-from-TESOL-2014-1-5-Billion-English-Le arners-Worldwide.

Block, P. (2013). Stewardship: Choosing Service Over Self-Interest. San Francisco, CA: Jossey-Bass.

Caldwell, C. (2010). A Ten-Step Model for Academic Integrity: A Positive Approach for Business Schools. Journal of Business Ethics, 92(1), 1-13. https://doi.org/10.1007/s10551-009-0144-7

Caldwell, C., \& Jeane, L. (2007). Ethical Leadership and Building Trust - Raising the Bar for Business. Journal of Academic Ethics, 5(1), 1-4. https://doi.org/10.1007/s10805-007-9044-6

Caldwell, C., Karri, R., \& Matula, T. (2005). Practicing What We Teach - Ethical Considerations for Business Schools. Journal of Academic Ethics, 3, 1-25. https://doi.org/10.1007/s10805-006-9007-3

Caldwell, C., White, H., \& Red Owl, R. H. (2007). The Case for Creating a DBA Program - A Virtue-Based Opportunity for Universities. Journal of Academic Ethics, 5(2-4), 179-188. https://doi.org/10.1007/s10805-007-9030-z

Camera, L. (2016). High School Seniors Aren’t College-Ready. U. S. News and World Report April 27, 2016 found online on $\quad$ December $\quad 19, \quad 2017$ at https://www.usnews.com/news/articles/2016-04-27/high-school-seniors-arent-college-ready-naep-data-show.

Canavor, N. C. (2018). Business Writing Today: A Practical Guide. Thousand Oaks, CA: Sage.

Chilton, M. (2012). Ernest Hemingway Wrote 47 Endings to A Farewell to Arms." The Telegraph, July 5, 2012 found online on January $18, \quad 2018$ at http://www.telegraph.co.uk/culture/books/booknews/9378446/Ernest-Hemingway-wrote-47-endings-to-A-Fare well-To-Arms.html.

Covey, S. R. (2004). The $8^{\text {th }}$ Habit: From Effectiveness to Greatness. New York: Free Press.

Davidson, W. \& Emig, J. (2015). Business Writing: What Works, What Won't (3 ${ }^{\text {rd }}$ Ed.). New York: St. Martins Griffin.

Dillon, S. (2009). Large Urban Suburban Gap Seen in Graduation Rates. New York Times, April 22, 2009, page A14 found online on December 19, 2017 at http://www.nytimes.com/2009/04/22/education/22dropout.html. 
Fee H., Greenan, K. \& Wall A. (2010). An Investigation into Secondary School Exit Standards: Implications for University Lecturers. International Journal of Management Education, 8(2), 43-52. https://doi.org/10.3794/ijme.82.269

Garner, B. A. (2013). HBR Guide to Better Business Writing: Engage Readers, Tighten and Brighten, Make Your Case. Boston, MA: Harvard Business Review Press.

Grammarly, Inc. (2017). Grammarly. found online on December 19, 2017 at https://www.grammarly.com/?q=grammar\&utm_source=bing\&utm_medium=cpc\&utm_campaign=Brand\&utm _term $=\% 2$ Bgrammery $\% 20$ com\&matchtype $=b \& m s c l k i d=47 \mathrm{ed} 3641094 \mathrm{e} 1 \mathrm{~b} 09 \mathrm{c} 6306 \mathrm{c} 788 \mathrm{e} 26 \mathrm{e} 60 \mathrm{a}$.

Griffin, F. (2001). The Business of the Business Writing Center. Business Communication Quarterly, 64(3), 70-79. https://doi.org/10.1177/108056990106400306

Hasan, J. (2016). AACSB's Benign Neglect of Faculty Teaching Effectiveness and Excessive Emphasis on Research Productivity: Profess or Perish vs. Publish or Perish. Academy of Business Journal, 1, 29-45.

Kahn, E., Johannessen, L. R., McCann, T., \& Smagorinsky, P. (2012). Teaching Students to Write Research Reports. London, UK: Heinemann Publishing.

Kotzee, B. \& Johnson, R. (2011). 'Can't String a Sentence Together'? UK Employers' Views of Graduates' Writing Skills. Industry and Higher Education, 25(1), 45-52. https://doi.org/10.5367/ihe.2011.0026

Mac Donald, Heather. (1995). Why Johnny Can’t Write. The Public Interest, 120, 3-13.

Mannino, L. L. \& Shoaf, V. (2007). Writing Assessment: The Use of Rubrics. Proceedings of the Northeast Business \& Economics Association, 299-302.

Max, T. (2016). The One Unbreakable Rule in Business Writing. Harvard Business Review. Digital Articles 9/13/2016.

May, G. L., Thompson, M. A., \& Hebblethwaite, J. (2012). A Process for Assessing and Improving Business Writing at the MBA Level. Business Communication Quarterly, 75(3), 252-270. https://doi.org/10.1177/1080569912441822

Mintzberg, H. (2005). Managers Not MBAs: A Hard Look at the Soft Practice of Managing and Management Development. San Francisco, CA: Berrett-Koehler Publishers.

Moore, K., (2016). Study: Poor Writing Skills are Costing Businesses Billions. Inc. March 31, 2016 and found online on December $\quad 19, \quad 2017$ at https://www.inc.com/kaleigh-moore/study-poor-writing-skills-are-costing-businesses-billions.html.

Parent, J. D., Nielsen-Dube, K., Stowe, K. F., Schwartz, L. A〉, Sendall, P. \& Cain, K. S. (2011). Successful Writing Skill Acquisition Within the Business Curriculum. Journal of the Academy of Business Education, 12, 56-73.

Pfeffer, J. \& Fong, C. T. (2002). The End of Business Schools? Less Success Than Meets the Eye. Academy of Management Learning \& Education, 1(1), 78-95. https://doi.org/10.5465/AMLE.2002.7373679

Routman, R. (2004). Writing Essentials: Raising Expectations and Results While Simplifying Teaching. London, UK: Heinemann Publishing.

Ruppert, B. Weihrich S. \& Carpenter, M. (2012). Identifying Need and Measuring Improvement in MBA Writing. Journal of the Academy of Business Education, 13, 129-139.

Rutenberg, D. (2009). High School Literacy: A Quick Stats Fact Sheet. Washington, D. C.: National High School Center American Institutes for Research found online on December 19, 2017 at http://www.air.org/project/national-high-school-center.

Saulnier, B. (2016). The Application of Writing Across the Curriculum (WAC) Techniques in a System Analysis \& Design Flipped Classroom. Information Systems Education Journal, 14(4), 13-19.

Selingo, J. J. (2017). Why Can't College Graduates Write Coherent Prose? Washington Post, August 11. Found online on January $\quad 18, \quad 2018 \quad$ at https://www.washingtonpost.com/news/grade-point/wp/2017/08/11/why-cant-college-graduates-write/

Simon, H. A. (1997). Administrative Behavior ( $4^{\text {th }}$ ed.). New York: Free Press.

Scholtes, P. R. \& Joiner, B. L. (2003). The TEAM Handbook ( $3^{\text {rd }}$ ed.) New York: Oriel Press. 
Stevens, B. (2005). What Communication Skills Do Employers Want? Silicon Valley Recruiters Respond. Journal of Employment Counseling, 42(1), 2-9. https://doi.org/10.1002/j.2161-1920.2005.tb00893.x

Sultan, N. (2013). British Students' Academic Writing - Can Academia Help Improve the Writing Skills of Tomorrow's Professionals? Industry and Higher Education, 27(2), 139-147. https://doi.org/10.5367/ihe.2013.0145

Sundem, G. (2006). Improving Student Writing Skills. Huntington Beach, CA: Shell Education.

Turnitin.com (2017). Turnitin for Higher Education. found online on December 19, 2017 at http://turnitin.com/en_us/higher-education.

Varner, I. I. \& Pomerenke, P. J. (1998). Assessing Competency in Business Writing. Business Communication Quarterly, 61(4), 83-91. https://doi.org/10.1177/108056999806100410

Whetten, D. (2001). What Matters Most. Academy of Management Review, 26(2), 175-178. https://doi.org/10.5465/AMR.2001.4378008 